\title{
Is the recent decrease in airborne Ambrosia pollen in the Milan area due to the accidental introduction of the ragweed leaf beetle Ophraella communa?
}

\author{
M. Bonini $\cdot$ B. Šikoparija $\cdot$ M. Prentović $\cdot$ G. Cislaghi • \\ P. Colombo $\cdot$ C. Testoni $\cdot$ L. Grewling $\cdot$ S. T. E. Lommen • \\ H. Müller-Schärer · M. Smith
}

\begin{abstract}
This study aims to determine whether a significant decrease in airborne concentrations of Ambrosia pollen witnessed in the north-west of the Province of Milan in Northern Italy could be explained by environmental factors such as meteorology, or whether there is evidence to support the hypothesis that the decrease was related to the presence of large numbers of the oligophagous Ophraella communa leaf beetles that are used as a biological control agent against Ambrosia in other parts of the world. Airborne concentrations of Ambrosia, Cannabaceae and Urticaceae
\end{abstract}

M. Bonini $(\square)$ · G. Cislaghi · P. Colombo · C. Testoni Department of Medical Prevention, Public Health, Local Health Authority of Milan 1, Parabiago (Mi), Italy

e-mail: maira.bonini@aslmi1.mi.it

\section{B. Šikoparija · M. Prentović}

Laboratory for Palynology, Department of Biology and Ecology, Faculty of Sciences, University of Novi Sad, Novi Sad, Serbia

\section{Prentović}

Department of Oto-Rhino-Laryngology, Research Group Aerobiology and Pollen information, Medical University of Vienna, Vienna, Austria

L. Grewling · M. Smith

Laboratory of Aeropalynology, Faculty of Biology, Adam Mickiewicz University, Poznań, Poland

S. T. E. Lommen · H. Müller-Schärer Department Biology, University of Fribourg, Fribourg, Switzerland pollen data (2000-2013) were examined for trends over time and correlated with meteorological data. The amount of Ambrosia pollen recorded annually during the main flowering period of Ambrosia (AugustSeptember) was entered into linear regression models with meteorological data in order to determine whether the amount of airborne Ambrosia pollen recorded in 2013 was lower than would normally be expected based on the prevailing weather conditions. There were a number of significant correlations between concentrations of airborne Ambrosia, Cannabaceae and Urticaceae pollen, as well as between airborne pollen concentrations and daily and monthly meteorological data. The linear regression models greatly overestimated the amount of airborne Ambrosia pollen in 2013. The results of the regression analysis support the hypothesis that the observed decrease in airborne Ambrosia pollen may indeed be related to the presence of large numbers of $O$. communa in the Milan area, as the drastic decrease in airborne Ambrosia pollen in 2013 cannot be explained by meteorology alone.

Keywords Aerobiology $\cdot$ Ragweed $\cdot$ Ophraella communa $\cdot$ Biocontrol agent

\section{Introduction}

Ambrosia maritima L. is the only Ambrosia (ragweed) species native to Europe; three other species of Ambrosia (A. psilostachya, A. tenuifolia and A. trifida) 
were introduced to Europe from North America in shipments of agricultural products (Smith et al. 2013). Of these introduced species, the invasive alien Ambrosia artemisiifolia L. (common or short ragweed) is the most widely distributed and as such is considered to be an import weed in agriculture and source of highly allergenic pollen, which causes symptoms of pollen allergy in late summer and autumn and reportedly induces asthma about twice as often as other pollen types (Dahl et al. (1999) and references therein).

The Rhône Valley (France), parts of Northern Italy, the Pannonian Plain (i.e. predominantly Hungary but also parts of Austria, Bosnia and Herzegovina, Croatia, Czech Republic, Romania, Serbia, Slovakia and Slovenia) and Ukraine are considered to be the most important sources of Ambrosia pollen in Europe (Smith et al. (2013) references therein). Ambrosia artemisiifolia is an anemophilous (wind pollinated) plant, the pollen grains of which can readily become airborne when conditions are favourable. As with other wind-pollinated plants, such as those belonging to the Cannabaceae and Urticaceae families that flower at around the same time as Ambrosia, pollen release and dispersal is aided by high temperature and low relative humidity (Dahl et al. (2013) and references therein).

Ophraella communa LeSage 1986 (Coleoptera: Chrysomelidae) is an oligophagous leaf beetle that feeds on various plants species belonging to the tribe Heliantheae (Asteraceae), including A. artemisiifolia (Futuyma and MCCafferty 1990; Palmer and Goeden 1991). The beetle originates from North America (Futuyma and MCCafferty 1990) and has been (accidentally) introduced to a number of other areas worldwide, including Europe, where it was first detected in 2013 (Takizawa et al. 1999; Meng and Li 2005; Müller-Schärer et al. 2014). Despite extensive host-specificity tests carried out over the past two decades (reviewed by Zhou et al. (2011)), there remains a controversial debate mainly on whether the beetle can attack and damage sunflower, Helianthus annuus L., in the field (cf. Müller-Schärer et al. (2014) and references therein). Therefore, hostspecificity tests both under quarantine and open-field conditions in Switzerland and Northern Italy and including various sunflower varieties and Ambrosia species are presently underway (H. Müller-Schärer, unpublished results) to decide on whether this beetle should be considered a troublesome introduction or whether it is likely to become the first case of a successful biological control of an invasive weed in continental Europe.

Ophraella communa is multivoltine in that it produces three or four generations per year, with an egg-to-egg generation time of about 4 weeks (Futuyma et al. 1993). Females lay eggs every few days for a month or more, with the fecundity exceeding 2700 eggs/female (Futuyma et al. 1993; Zhou et al. 2010b). The survival rate of eggs and larvae is higher, and the development periods shorter, when temperature and humidity are increased (Zhou et al. 2010a, b; Zhu et al. 2012). Both the larva and imago feed on leaves of $A$. artemisiifolia (Wan et al. 2009). O. communa can significantly suppress plant height and the number of branches (Guo et al. 2011), and when beetle densities are high enough, it can even kill all Ambrosia plants (Zhou et al. 2014), thus preventing the production of seeds. Required densities are higher when plants are bigger, but even plants that were only experimentally exposed to the beetles when they were already over $90 \mathrm{~cm}$ tall were successfully killed prior to seed production (Zhou et al. 2014). In addition, $O$. communa has high dispersal potential (Tanaka and Yamanaka 2009). The flight distance has been estimated to be approximately $25 \mathrm{~km} /$ day, with potential range expansion of $329 \mathrm{~km} /$ year (Yamamura et al. 2007; Tanaka and Yamanaka 2009). Taking into account the selective host-feeding preferences, high fecundity and dispersal potential, it is suggested that O. communa may be a potential biological control agent against $A$. artemisiifolia (Teshler et al. 2002) although Ophraella slobodkini was a preferred candidate species for the biological control of A. artemisiifolia in Europe, because it exclusively feeds on Ambrosia (Gerber et al. 2011).

Ophraella communa beetles were observed feeding on Ambrosia artemisiifolia plants in several regions of Northern Italy, especially near Milan (Bosio et al. 2014; Müller-Schärer et al. 2014), during the summer of 2013. The beetle was found on all observed ragweed populations. Individual A. artemisiifolia plants harboured up to over a hundred beetles, and many plants were completely defoliated before the end of the season (Müller-Schärer et al. 2014). At the same time, it was noticed that routine pollen-monitoring stations situated in three towns of the north-west area of the Province of Milan were recording less Ambrosia 
pollen than usual. This study aims to determine whether the observed decrease in airborne concentrations of Ambrosia pollen can be explained by environmental factors such as meteorology that are known to strongly affect pollen release and dispersal, or whether there is evidence to support the hypothesis that the decrease was related to the presence of $O$. communa in the area.

\section{Materials and methods}

\subsection{Airborne pollen data}

Daily average pollen concentrations were collected at three sites in the north-west area of the Province of Milan, Northern Italy, from 2000 to 2013 (Fig. 1). Pollen data were collected by volumetric spore trap of the Hirst design (Hirst 1952). The pollen-monitoring sites were the towns of Legnano (ITMIL6), Magenta (ITMAGE) and Rho (ITRHO1). Legnano is the closest pollen-monitoring site to the meteorological stations, and so pollen data from this site were used throughout the analysis. Legnano is also the only pollen-monitoring site in this study where all three pollen types examined, Ambrosia, Cannabaceae and Urticaceae, are routinely monitored.

The amount of Ambrosia pollen recorded annually during the main flowering period of Ambrosia (AugustSeptember) is presented (Annual Ambrosia PollenAAP). The mean AAP of all three sites combined was also examined and termed "Milan area". In addition, the amounts of Cannabaceae pollen (Annual Cannabaceae Pollen-ACP) and Urticaceae pollen (Annual Urticaceae Pollen-AUP) recorded during August-September at Legnano were included in the study as these taxa contain species that flower in August-September. As a result, the amount of these pollen types in the air can be assumed to be influenced by similar meteorological factors as Ambrosia. We therefore hypothesised that if airborne Cannabaceae and Urticaceae pollen concentrations do not follow a similar trend as Ambrosia pollen, i.e. the ACP and AUP did not decrease in the same way as AAP, then weather conditions during the period of pollen release are unlikely to be the main factor affecting airborne Ambrosia pollen concentrations. This would provide support for the hypothesis that the observed decrease in AAP was due to the presence of O. communa in the area, rather than meteorology. On the other hand, concurrent decreases in all three pollen types would

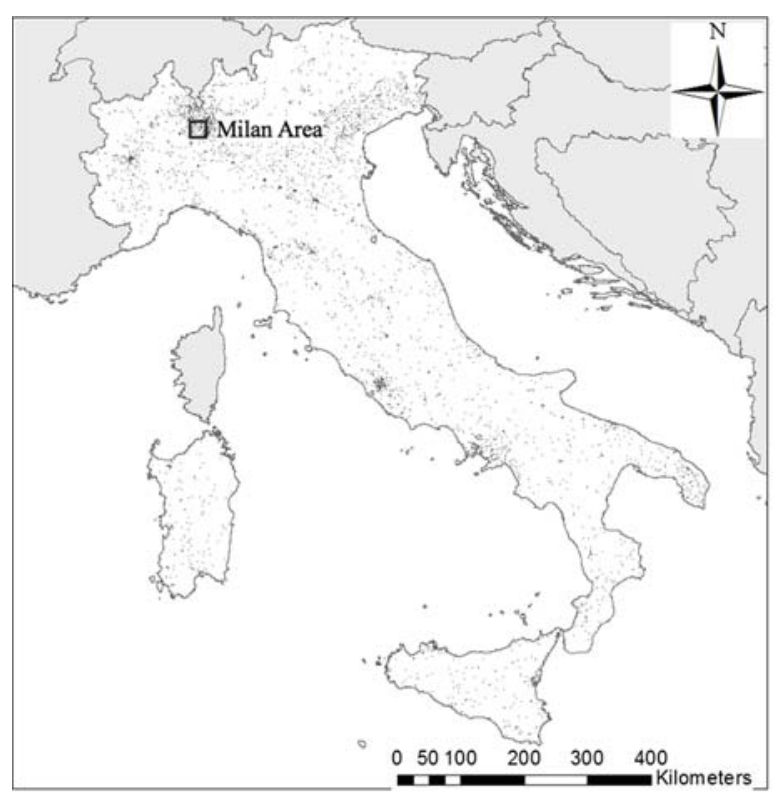

Italy and major urban areas

Urban area

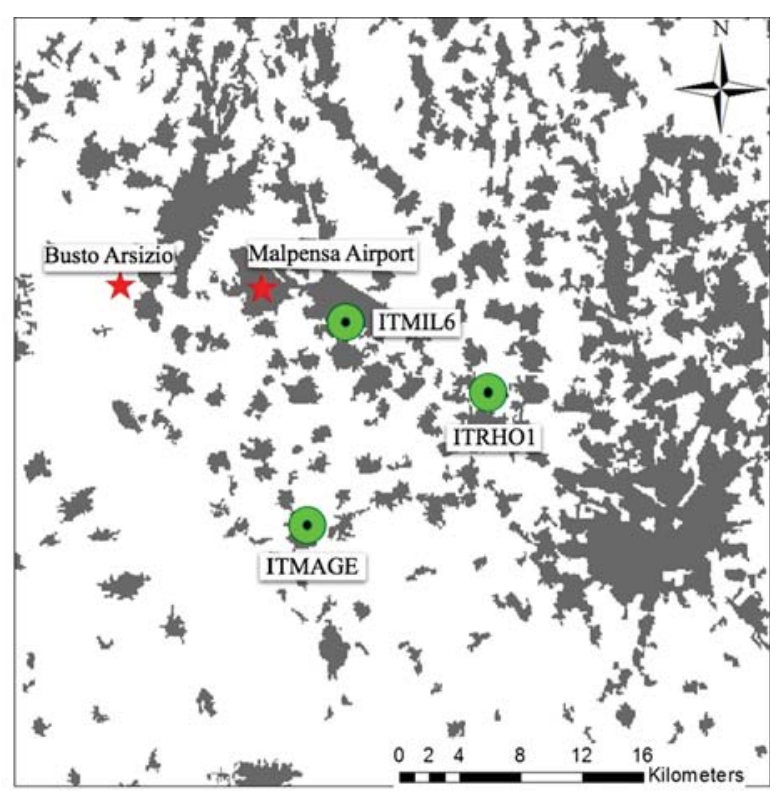

Observational sites in the Milan region
- Pollen Urban area

Fig. 1 Position of the pollen-monitoring sites and meteorology stations in the Milan region (Italy) 
suggest that either conditions during August and September 2013 were generally not conducive for the release and dispersal of anemophilous pollen or that other factors which can affect the amount of pollen in the air from these three pollen types should be considered.

With this in mind, the following should be noted: (1) Cannabaceae and Urticaceae species tend to grow in similar habitats as Ambrosia (e.g. Cannabis on ruderal habitats and agricultural land, and Urtica/Parietaria on ruderal habitats); (2) All host-range tests conducted so far indicate that $O$. communa is specific to the Asteraceae tribe Heliantheae (Palmer and Goeden 1991; Gerber et al. 2011). As a result, Cannabaceae and Urticaceae populations could be affected by Ambrosia eradication measures in the Milan area, and concurrent decreases in airborne Cannabaceae and Urticaceae pollen are unlikely to be caused by beetle attacks.

Daily average pollen concentrations are expressed as particles per cubic metre of air $\left(\mathrm{P} \mathrm{m}^{-3}\right)$ (Comtois 1998). The amount of pollen recorded during August and September (AAP, ACP and AUP) is presented as grains.

\subsection{Meteorological data}

Meteorological data were collected at Malpensa airport and accessed via http://www.tutiempo.net. The following daily meteorological variables were examined: $T$, mean temperature $\left({ }^{\circ} \mathrm{C}\right) ; T_{\max }$, maximum temperature $\left({ }^{\circ} \mathrm{C}\right) ; T_{\min }$, minimum temperature $\left({ }^{\circ} \mathrm{C}\right) ; \mathrm{H}$, mean humidity (\%); PP, precipitation amount (mm); $\mathrm{V}$, mean wind speed $(\mathrm{Km} / \mathrm{h}) ; \mathrm{VM}$, maximum sustained wind speed $(\mathrm{Km} / \mathrm{h})$; RN, indicator for occurrence of rain or drizzle; $\mathrm{SN}$, indicator for occurrence of snow or ice Pellets; FG, indicator for occurrence of fog. Meteorological data for Malpensa airport were not available for analysis: $2002-26-31.05 .2002 ; 2002-$ 18-21.06.2002; 2005-13-30.11.2005; 200728.8.2007; 2008-18.8.2008; 2013-1-31.12.2013. In addition, daily average wind direction data were obtained from Busto Arsizio meteorological station, which is situated close to Legnano (ITMIL6) pollenmonitoring station and the meteorological station at Malpensa airport (Fig. 1).

\subsection{Statistical analysis}

Data were examined for normality using the Kolmogorov-Smirnov test. Where data were found to be normally distributed, parametric statistics were applied; where data were not normally distributed, nonparametric statistics were used (Sterling et al. 1999).

Annual variations in the amount of airborne pollen recorded during August and September were normally distributed. Analysis of variance (ANOVA) was used to determine whether there was a significant difference in the mean AAP recorded at the three sites (2000-2013). Also, Pearson's correlation analysis was carried out between AAP recorded at all three sites included in the study, as well as between AAP, ACP and AUP recorded at Legnano. Trends in the amount of Ambrosia, Cannabaceae and Urticaceae pollen recorded in three periods (2000-2011, 2000-2012 and 2000-2013) were examined using simple linear regression analysis. The following statistics are presented: the slope of the simple linear regression over time, standard error of the regression slope (SE) and probability level $(p)$.

Conversely, daily variations in airborne pollen and variations in meteorological data (daily and monthly) were often not normally distributed. As a result, Spearman's rank correlation analysis was used to examine relationships between the following: (1) daily average concentrations of airborne Ambrosia pollen with daily average concentrations of airborne Cannabaceae and Urticaceae pollen; (2) daily average concentrations of airborne Ambrosia, Cannabaceae and Urticaceae pollen with all of the daily meteorological data listed in Sect. 2.2 (not wind direction); (3) AAP with monthly meteorological data recorded from January through to September in the year of pollination. The latter was used to determine whether there was a relationship between the amount of airborne Ambrosia pollen recorded in August and September and meteorological variables likely to influence the production, release and dispersal of Ambrosia pollen. The monthly meteorological data were as follows: monthly averages of daily temperature (daily minimum, mean and maximum temperatures), daily average relative humidity and daily precipitation; the monthly sum of daily precipitation; the number of days with rain, fog and drizzle recorded in each month. In addition, two monthly sums and averages of precipitation, humidity and temperature were also entered into correlation analysis with AAP. Data from 2013 were not entered into Spearman's rank correlation analysis, as this was the year under investigation (2000-2012 only).

Simple linear and multiple linear regression models were constructed in order to predict AAP in "below 
average", "above average" and "low intensity" years (Sect. 2.4) recorded at Legnano, which is the site closest to the meteorological station at Malpensa airport (Fig. 1). The justification for this extra analysis is that if the models were unable to satisfactorily predict the AAP in 2013, then this would add weight to the argument that the observed decrease in airborne concentrations of Ambrosia pollen cannot be explained by meteorology and add support to the hypothesis that the decrease was related to the presence of $O$. communa in the area. Independent variables that were not normally distributed were normalised using the LOG10 function (Stach et al. 2008). Spearman's correlation analysis was then repeated, in order to ensure that normalisation had not notably altered the strength and direction of the relationship between dependent and independent variables.

Tests were considered significant with probability levels $<0.05$. All calculations and statistical analysis of the data were conducted using Microsoft Excel and SPSS 12.0 software packages.

\subsection{Model for predicting annual variations in Ambrosia pollen (AAP)}

The independent variables with the strongest relationship with AAP were entered into simple linear and multiple linear regression analysis. The regression models were primarily constructed in order to investigate whether the AAP in 2013 was lower than would normally be expected based on the prevailing weather conditions. The regression models were also validated using data deemed to be characteristic of "below average" (2010) and "above average" (2009) magnitude AAP years (note that 2013 recorded the lowest AAP in the 2000-2013 data set and was therefore deemed to be a "low intensity" year).

The regression models were calibrated using 11 years of Ambrosia pollen and environmental data (2000-2008, 2011 and 2012). These years were not included in the validation process. The models were validated (tested) using 2 years of data not included in model construction. Following the method described by Prentović et al. (2014), it was decided not to test the performance of the model using the two most recent years of data (i.e. 2011 and 2012). This was because both of these years were representative of low AAP years. Instead, it was decided to validate the model using data that were characteristic of both low and high seasons (but not the years with the lowest and highest AAP in the data set). For this reason, the AAP in each year was categorised as being "below average" or "above average". The years with the mean AAP in each group (e.g. the mean of all "below average" years) were selected for validation. The 2 years selected were 2010 (mean of all "below average" years) and 2009 (mean of all "above average" years). The regression models were then validated using the AAP from selected validation years (2009 and 2010), as well as 2013.

The models were evaluated by examining: (a) the adjusted coefficient of determination (Adj. $\mathrm{R}^{2}$ ), which is considered more appropriate for evaluating regression models developed on small samples (Pallant 2001); (b) the Kolmogorov-Smirnov test (normality of the residuals); (c) the Koenker-Basset test for heteroscedasticity, for violation of homogeneity of the residuals variance (Bickel 2012); (d) collinearity diagnostics were carried out by checking the variance inflation factor (VIF) and computing the Mahalanobis distance (Pallant 2001).

\subsection{Examining land use change in the Milan area}

Common ragweed is a pioneer plant that is known to prefer open, disturbed sites (Essl et al. 2009) and tends to grow in suitable habitats if two conditions are fulfilled (Skjøth et al. 2010): (1) available seeds; (2) soil disturbance. For this reason, major construction works in the Milan area 2000-2013 were examined in order to determine whether changes in land use could be related to the decrease in airborne concentrations of Ambrosia pollen in 2013. Information about construction sites were accessed via the Local Health Authority Milan 1, Department of Medical Prevention, UOC SPreSAL, Internal Archive. The "UOC SPreSAL" is the service that controls construction in the Milan area. Geographical coordinates were found by using Google Maps.

\section{Results}

3.1 Trends and relationships in the amount of airborne pollen

There is great deal of variation in AAP recorded at stations situated in the north-west of the Province of 
Milan (Table 1). The highest AAP was recorded in 2000, 2004 and 2009 in the Milan area (the highest was 2000 at Legnano and Rho and 2004 at Magenta). The lowest AAP was recorded in 2013 at all three sites. Note that the second lowest AAP was recorded in 2012, showing a notable decrease in recent years. The results of ANOVA showed that there was not a significant difference $(p>0.05)$ between the AAP recorded at the three sites, and Pearson's correlation analysis showed that AAP at these sites was also significantly (positively) related. The amount of airborne Urticaceae pollen recorded annually showed a similar pattern, with the highest AUP in 2000 and lowest AUP in 2013. The lowest amount of airborne Cannabaceae pollen was also recorded in 2013, but the highest ACP was in 2009.

There were a number of significant negative trends in AAP during the period 2000-2013 (Table 2). These significant trends in AAP were no longer evident when Ambrosia pollen data from 2013 and 2012 were removed from the analysis. The only site where there were no significant trends in AAP was Magenta, where the peak AAP was recorded in 2004. The significant negative trend was still apparent when data from all three sites were combined. There were no significant trends in ACP, but there were significant negative trends in AUP in all three periods (2000-2013, 2000-2012 and 2000-2011).

Cannabaceae and Urticaceae plants also flower in late summer, and their pollen is in the air at the same time as Ambrosia. The results of Spearman's correlation analysis showed that there were significant positive relationships between daily average concentrations of airborne Ambrosia pollen and airborne Cannabaceae pollen $(r=0.5582, p<0.001)$ and Urticaceae pollen $(r=0.648, p<0.001)$ recorded during August and September at the sites. There was also a significant positive correlation between daily average concentrations of airborne Cannabaceae pollen and airborne Urticaceae pollen $(r=0.714$, $p<0.001)$.

Pearson's correlation analysis showed that there was a significant relationship between AAP and ACP $(r=0.560, p=0.037)$ but not between AAP and AUP $(r=0.490, p=0.075)$ recorded at Legnano. Similarly, correlations were not significant between ACP and AUP at this site $(r=0.176$, $p=0.547)$.
3.2 The influence of meteorological data on airborne pollen concentrations

Daily average concentrations of airborne Ambrosia, Cannabaceae and Urticaceae pollen were entered in Spearman's correlation analysis with daily meteorological data (2000-2013). The results show that there were a number of significant correlations between daily average concentrations of airborne pollen and daily meteorological data recorded during August and September (Table 3). Daily average pollen concentrations were negatively correlated with precipitation and humidity and positively correlated with temperature. The only significant correlations with wind speed were seen with airborne Urticaceae pollen at Legnano (significant negative correlations). Wind direction was also examined. Wind roses (Fig. 2a-f) for daily average wind direction during August and September show that there was a higher than average frequency of winds from the Southeast in 2012 and 2013 (the years with the lowest AAP). Conversely, there was a higher frequency of winds from the South and Southwest in 2000 and 2004 (years with high AAP), although it should be noted that there was also a high frequency of Southeasterly winds in 2009 when the AAP also exceeded 6000 Ambrosia pollen grains (Fig. 2c; Table 1).

AAP recorded in Legnano was entered into Spearman's rank correlation analysis with monthly and two monthly averages of meteorological data recorded before August (examining pollen production) and during August and September (related to the release and dispersal of pollen from the plant) in the year of pollination. The only statistically significant correlations recorded were between AAP and the following (Fig. 3):

- Before the season-March $(r=-0.702$, $p=0.008)$ and June $(r=-0.634, p=0.020)$ averages of daily minimum temperatures, as well as June averages of daily relative humidity ( $r=$ $-0.676, p=0.011$ )

- During the season-September number of days with rain $(r=-0.656, p=0.015)$.

Climate data recorded at Malpensa airport (Table 4) show that in 2013 mean minimum temperatures in March and June, mean relative humidity in June and the number of days with rain in September 2013 were all below average (lower than the 1981-2010 mean). 


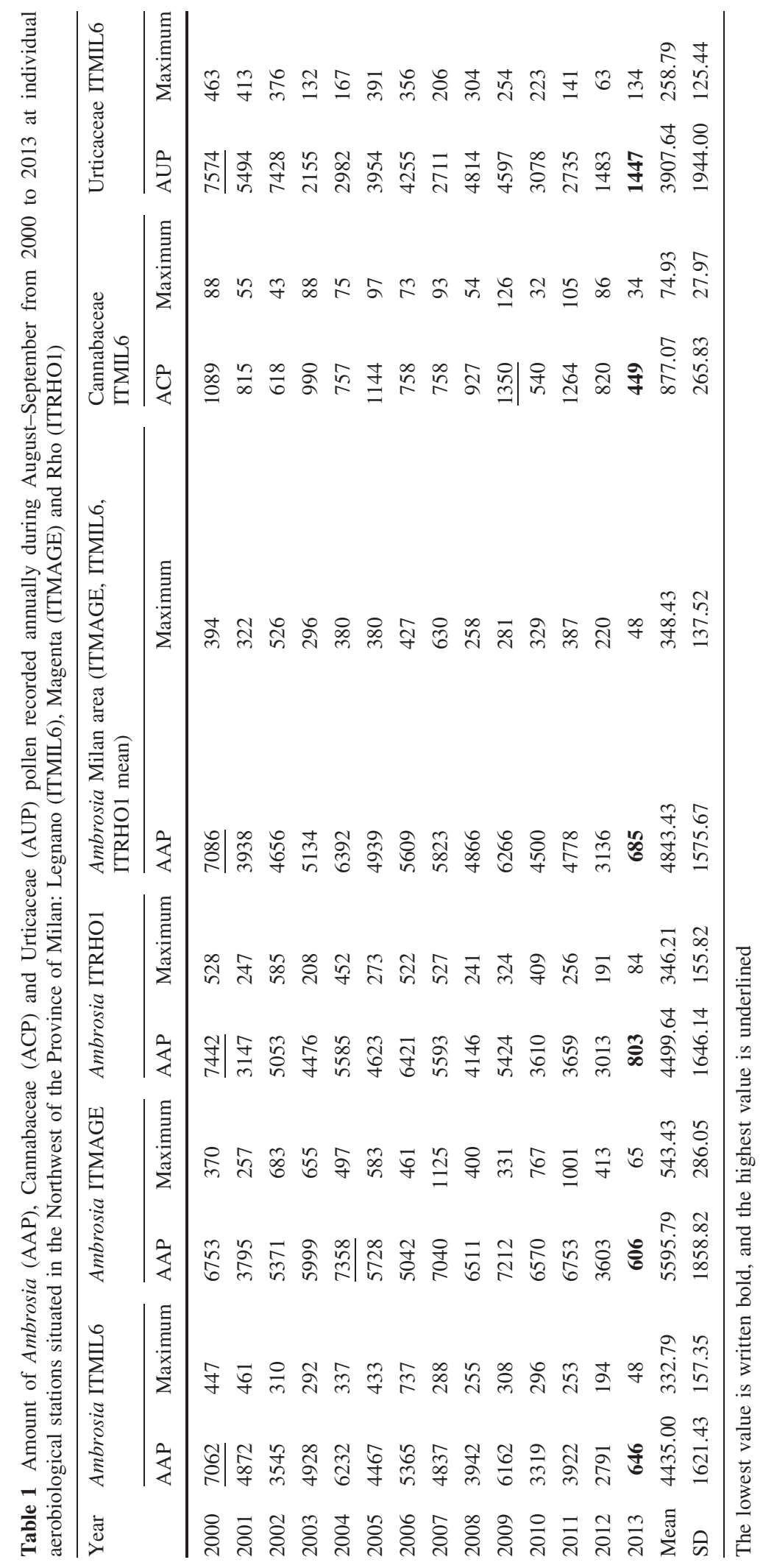


Table 2 Trends in the amount of airborne Ambrosia (AAP), Cannabaceae (ACP) and Urticaceae (AUP) pollen recorded annually in August-September in the Milan area during three periods (2000-2011, 2000-2012 and 2000-2013): slope of the regression over time (slope), standard error of the regression (SE) and probability level ( $p$ ). Legnano (ITMIL6), Magenta (ITMAGE) and Rho (ITRHO1)

\begin{tabular}{|c|c|c|c|c|c|c|c|c|c|}
\hline \multirow[t]{2}{*}{ Site } & \multicolumn{3}{|l|}{ 2000-2013 } & \multicolumn{3}{|l|}{ 2000-2012 } & \multicolumn{3}{|l|}{ 2000-2011 } \\
\hline & Slope & SE & $p$ & Slope & SE & $p$ & Slope & SE & $p$ \\
\hline AAP_-ITMIL6 & -256.312 & 83.932 & 0.01 & -174.659 & 81.091 & 0.054 & -134.318 & 91.905 & 0.175 \\
\hline AAP_ITMAGE & -136.200 & 122.096 & 0.286 & 21.665 & 94.871 & 0.824 & 135.601 & 80.886 & 0.125 \\
\hline AAP_ITRHO1 & -240.556 & 89.897 & 0.02 & -158.516 & 89.223 & 0.103 & -121.248 & 102.455 & 0.264 \\
\hline AAP_-Milan area & -211.023 & 90.065 & $\mathbf{0 . 0 3 7}$ & -103.837 & 76.415 & 0.201 & -39.988 & 79.200 & 0.625 \\
\hline ACP_ITMIL6 & -0.069 & 18.225 & 0.699 & 7.434 & 18.849 & 0.701 & 13.552 & 21.907 & 0.550 \\
\hline AUP_ITMIL6 & -330.631 & 94.266 & 0.004 & -318.648 & 109.782 & 0.014 & -286.738 & 128.054 & 0.049 \\
\hline
\end{tabular}

Bold values are signify the probability level

Table 3 Results of Spearman's rank correlation analysis between daily average Ambrosia, Cannabaceae and Urticaceae pollen concentrations (August-September) and daily meteorological data. $T$ mean temperature $\left({ }^{\circ} \mathrm{C}\right), T_{\max }$ maximum temperature $\left({ }^{\circ} \mathrm{C}\right), T_{\min }$ minimum temperature $\left({ }^{\circ} \mathrm{C}\right), H$ mean humidity $(\%)$, PP precipitation amount $(\mathrm{mm}), V$ mean wind speed $(\mathrm{Km} / \mathrm{h}), \mathrm{VM}$ maximum sustained wind speed $(\mathrm{Km} / \mathrm{h})$

\begin{tabular}{llll}
\hline & $\begin{array}{l}\text { Ambrosia Milan area } \\
\text { (ITMAGE, ITMIL6, } \\
\text { ITRHO1 mean) }\end{array}$ & $\begin{array}{l}\text { Cannabaceae } \\
\text { ITMIL6 }\end{array}$ & $\begin{array}{l}\text { Urticaceae } \\
\text { ITMIL6 }\end{array}$ \\
\hline $\mathrm{PP}$ & $-0.093 * *$ & $-0.183 * *$ & $-0.164 * *$ \\
$\mathrm{H}$ & $-0.140 * *$ & $-0.256 * *$ & $-0.125 * *$ \\
$T_{\min }$ & $0.119 * *$ & $0.439 * *$ & $0.351 * *$ \\
$T_{\max }$ & $0.176 * *$ & $0.556 * *$ & $0.429 * *$ \\
$\mathrm{~T}$ & $0.184 * *$ & $0.567 * *$ & $0.470 * *$ \\
$\mathrm{~V}$ & -0.008 & 0.030 & $-0.124 * *$ \\
$\mathrm{VM}$ & -0.024 & 0.000 & $-0.135 * *$ \\
\hline
\end{tabular}

* Correlation is significant at the 0.05 level (two tailed)

** Correlation is significant at the 0.01 level (two tailed)

\subsection{Regression analysis}

Simple linear and standard multiple regression models were constructed for predicting the AAP in Legnano during 2009 and 2010 (the validation years) as well as 2013 (the year under investigation), using meteorology parameters that were significantly correlated with AAP. The final models are presented in Table 5. The only models that were statistically significant were the simple linear regression model using the number of days with precipitation in September and standard multiple regression models using: (1) March averages of daily minimum temperature and the number of days with precipitation in September and (2) June averages of daily relative humidity and the number of days with precipitation in September. In general, actual and predicted values for AAP were reasonably close in both 2009 and 2010. The main exception is the simple linear regression model that included the number of days with precipitation in September, which overestimated AAP in 2010. There was a close agreement between the models in 2013, but all three models greatly overestimated AAP in this year (Fig. 4).

\subsection{Land use change}

Examination of data from the UOC SPreSAL Internal Archive shows that there is no relationship between the number of large construction works (i.e. the Milan Fair, road and rail networks and building construction such as hospitals and residential buildings) and the significant decrease witnessed in AAP in the Milan area since 2000 (Table 6). No major construction works were listed as being undertaken during 2000 and 2001, when airborne concentrations of Ambrosia pollen were high. On the other hand, a number of major construction works have been in operation in recent years, such as residential building as well as road and rail links.

\section{Discussion}

This study investigates potential drivers of the significant decrease witnessed in Ambrosia pollen counts recorded in the Milan area in recent years. 
Fig. 2 Wind Roses for selected years, showing the frequency different daily average wind directions recorded at Busto Arsizio meteorological station during August and September in 2000-2013: a 2000; b 2004; c 2009; d 2012; e 2013; f 2000-2012 mean
(A)

2000

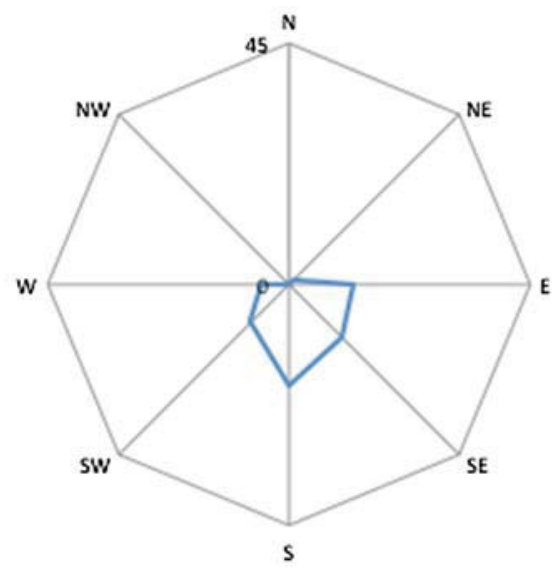

(C)

2009

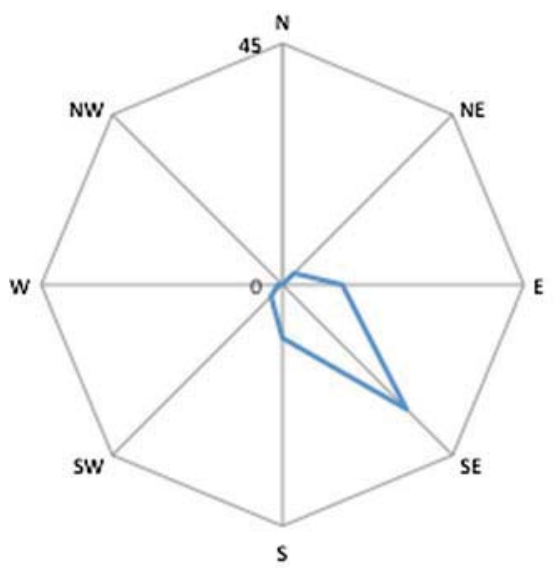

(E)

2013

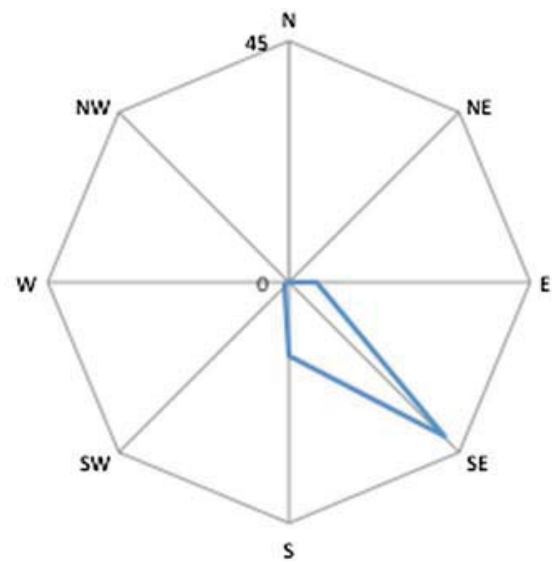

(B)

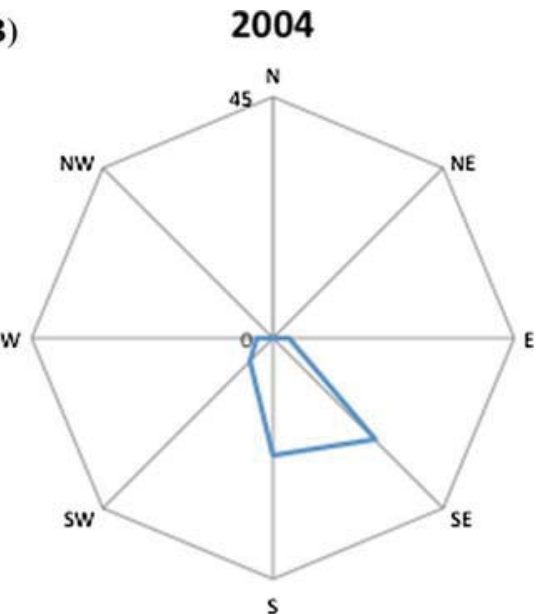

(D)
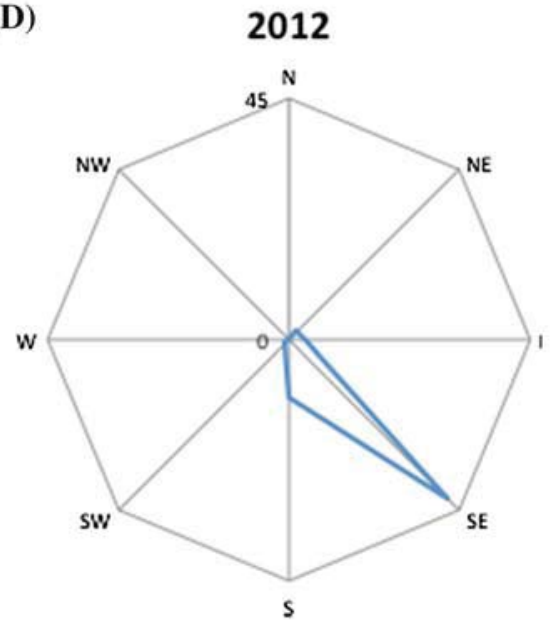

(F)

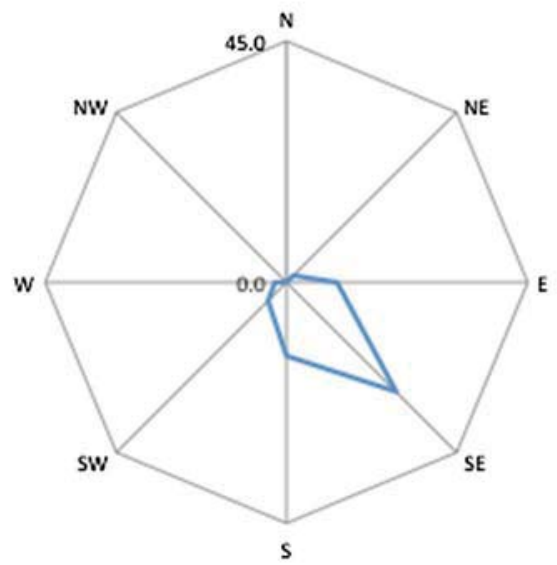

Concentrations of airborne Ambrosia pollen recorded at the three pollen-monitoring sites included in this study are closely related (determined by ANOVA and
Pearson's correlation analysis). This information, combined with the fact that this significant decrease is repeated at all three sites, suggests that this is a 
(A)

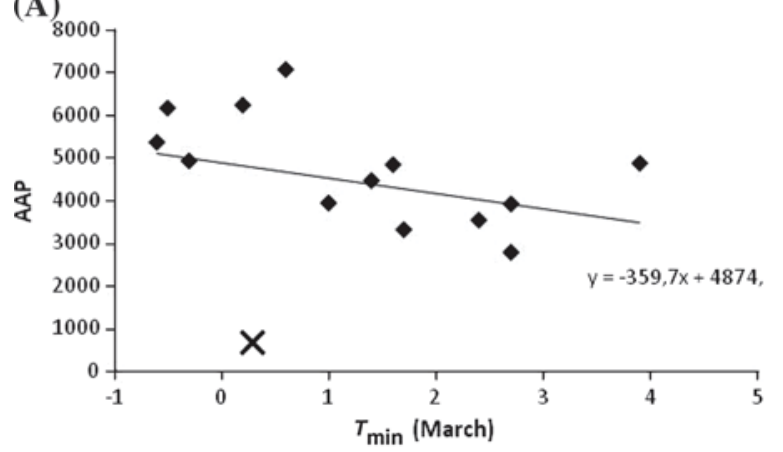

(C)

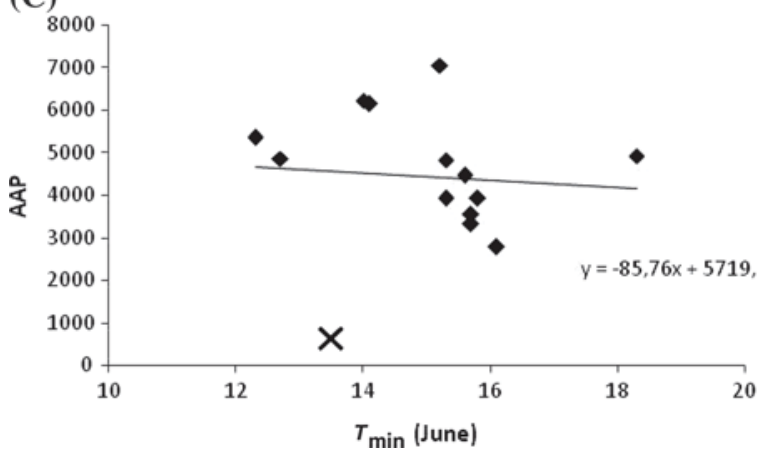

Fig. 3 Relationship between AAP and monthly average meteorological data with significant correlations: a March averages of daily minimum temperature, $\mathbf{b}$ June averages of daily relative humidity, c June averages of daily minimum temperatures, $(D)$ number of days with rain in September. Data from 2013 are marked as " $X$ ". Note that the negative

Table 4 Climate data recorded at Malpensa airport and accessed via http://www.tutiempo.net, showing 2013 values in relation to long-term mean for the period 1981-2010

\begin{tabular}{lrc}
\hline & \multicolumn{1}{c}{2013} & $1981-2010$ \\
\hline Mean annual $T_{\min }$ & 6.50 & 5.93 \\
Mean annual RN & 150.00 & 127.14 \\
$T_{\min }$ (March) & 0.30 & 0.58 \\
$T_{\min }$ (June) & 13.50 & 13.60 \\
$H$ (June) & 60.00 & 67.64 \\
RN (September) & 7.00 & 10.50 \\
\hline
\end{tabular}

$T_{\min }$ minimum temperature $\left({ }^{\circ} \mathrm{C}\right), \mathrm{H}$ mean humidity (\%), RN indicator for occurrence of rain or drizzle

regional scale phenomenon. The question that this study has attempted to answer is: Can this decrease be explained by environmental factors such as meteorology, or is there evidence to support the hypothesis that the decrease was related to the presence

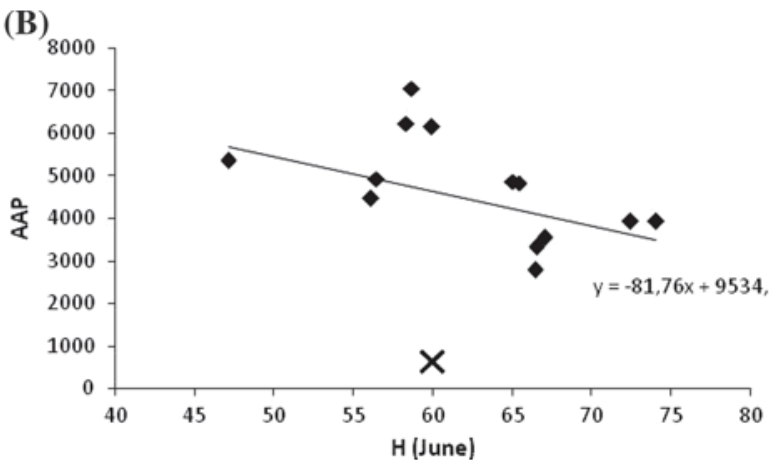

(D)

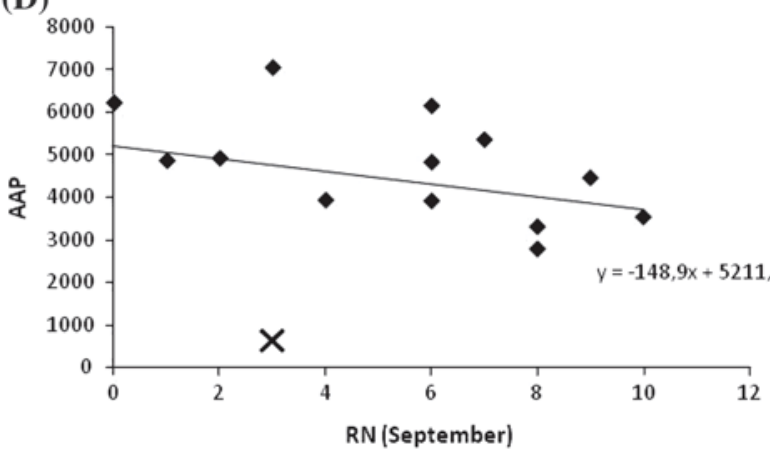

relationship with the monthly variables means that low values would normally result in high AAP. Many of the values are below average (e.g. $T_{\min }$ in June is the third lowest in the 2000-2013 data set), but the AAP in 2013 is extremely low. $T_{\min }$ minimum temperature $\left({ }^{\circ} \mathrm{C}\right), \mathrm{H}$ mean humidity $(\%), \mathrm{RN}$ indicator for occurrence of rain or drizzle

of large numbers of $O$. communa leaf beetles in the area?

Airborne concentrations of Ambrosia pollen recorded in the Milan area are influenced by weather conditions before and during the main flowering period of Ambrosia (August-September). The weather before the start of the season influences pollen production, and significant correlations were found between AAP and March and June averages of daily minimum temperatures, as well as June averages of daily relative humidity. The negative relationships between AAP and these variables suggest that lower temperatures in March and lower temperatures and lower rainfall in June favour the production of Ambrosia pollen. It should therefore be noted that minimum temperatures in March and June as well as relative humidity in June were all below average in 2013 (compared with the 1981-2010 mean) (Table 4).

The negative association with minimum temperatures in March could be caused by the relationship 
Table 5 Simple linear and standard multiple regression models for predicting AAP for Legnano

\begin{tabular}{|c|c|c|c|c|c|}
\hline $\begin{array}{l}\text { Model } \\
\text { no. }\end{array}$ & Regression equation & Adj. $R^{2}$ & $p$ & $\begin{array}{l}\text { Kolmogorov- } \\
\text { Smirnov test }(p)^{\mathrm{a}}\end{array}$ & $\begin{array}{l}\text { Koenker-Basset } \\
\text { test }(p)^{\text {b }}\end{array}$ \\
\hline 1 & $5392.861-471.691 * T_{\min }($ March $)$ & 0.222 & 0.081 & 0.172 & 0.876 \\
\hline 2 & $8263.214-234.109 * T_{\min }($ June $)$ & 0.002 & 0.339 & 0.200 & 0.410 \\
\hline 3 & $10,090.968-85.973 * H$ (June) & 0.241 & 0.072 & 0.200 & 0.337 \\
\hline 4 & $5860.751+223.308 * \mathrm{RN}$ (September) & 0.308 & 0.045 & 0.200 & 0.252 \\
\hline 5 & $9746.913-510.249 * T_{\min }($ March $)-248.385 * T_{\min }$ (June) & 0.310 & 0.093 & 0.200 & 0.592 \\
\hline 6 & $8460.430-262.836 * T_{\min }($ March)-53.883*H (June) & 0.207 & 0.162 & 0.200 & 0.551 \\
\hline 7 & $6234.579-380.312 * T_{\min }($ March)-190.795*RN (September) & 0.455 & 0.036 & 0.200 & 0.728 \\
\hline 8 & $8473.372-176.775 * T_{\min }($ June)-211.543* RN (September) & 0.292 & 0.103 & 0.200 & 0.792 \\
\hline 9 & 10,751.921-79.487*H (June)-209.352*RN (September) & 0.558 & 0.016 & 0.200 & 0.685 \\
\hline
\end{tabular}

Models calibrated using data not included in model validation. $T_{\min }$ (March) March averages of daily minimum temperatures $\left({ }^{\circ} \mathrm{C}\right)$, $T_{\min }$ (June) June averages of daily minimum temperatures $\left({ }^{\circ} \mathrm{C}\right), H$ (June) June averages of daily relative humidity $(\%)$, RN (September) number of days with precipitation (rain or drizzle) in September

Bold values are signify the probability level

${ }^{\mathrm{a}} p>0.05$ normality of residuals distribution is not violated

${ }^{\mathrm{b}} p>0.05$ homogeneity of residual variance (homoscedasticity) is not violated

Fig. 4 Performance of significant regression models in forecasting AAP in Legnano during mean "above average" (2009) and mean "below average" (2010) years, as well as AAP in 2013 (the year with the lowest AAP in the 2000-2013 dataset). $T_{\min }$ minimum temperature $\left({ }^{\circ} \mathrm{C}\right)$, $H$ mean humidity (\%), RN indicator for occurrence of rain or drizzle

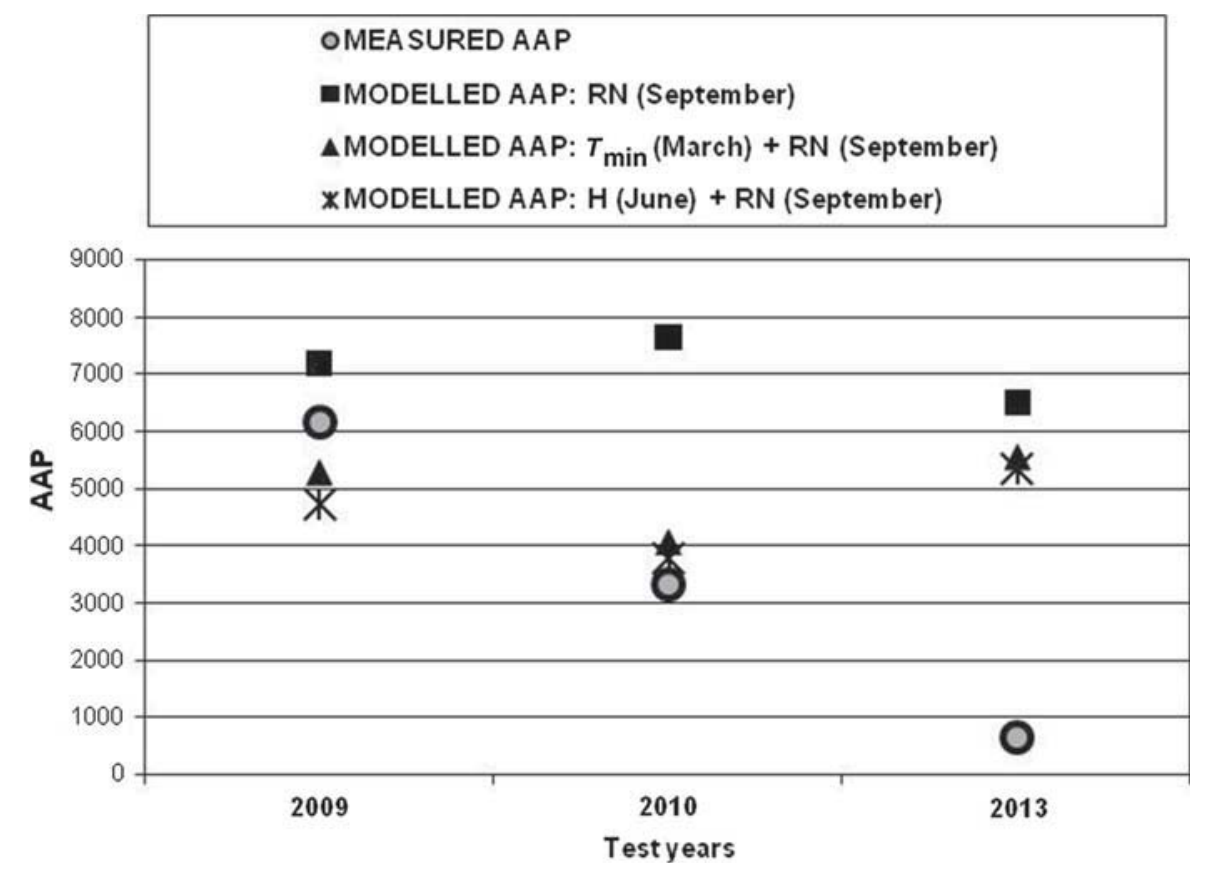

between germination success and the size of the source (i.e. the number of plants in the region). This is because Ambrosia seeds require moist chilling (stratification) before they can germinate (Pickett and Baskin 1973; Willemsen 1975; Baskin and Baskin 1977, 1980). Ambrosia plants that emerge earlier have been shown to grow larger, and Ambrosia pollen production is directly correlated with biomass (Rogers et al. 2006; Fumanal et al. 2007). In addition, lower temperatures in June may facilitate reproductive growth because, as seen with chrysanthemums (close relatives to both Ambrosia), exposure to high temperatures at the beginning of the short-day period results in a notable delay both in initiation and further 
Table 6 Major construction works in the Milan area 2000-2013

\begin{tabular}{|c|c|c|c|c|c|c|c|c|c|c|c|c|c|c|c|}
\hline $\begin{array}{c}\text { Construction } \\
\text { works }\end{array}$ & 2000 & 2001 & 2002 & 2003 & 2004 & 2005 & 2006 & 2007 & 2008 & 2009 & 2010 & 2011 & 2012 & 2013 & $\begin{array}{l}\text { Geographical } \\
\text { coordinates }\end{array}$ \\
\hline $\begin{array}{l}\text { Milan Fair (located in Rho-Pero) } \\
\text { from } 2002 \text { to } 2005\end{array}$ & & & & & & & & & & & & & & & $45.520796,9.078340$ \\
\hline $\begin{array}{l}\text { Three other large roadworks located in } \\
\text { Rho-Pero from } 2002 \text { to } 2005\end{array}$ & & & & & & & & & & & & & & & $\begin{array}{l}45.520796,9.078340 \text { and the } \\
\text { surroundings }\end{array}$ \\
\hline $\begin{array}{l}\text { TAV (TGV) rail line } \\
\text { from } 2005 \text { to } 2010\end{array}$ & & & & & & & & & & & & & & & $\begin{array}{l}\text { From } 45.4723836,8.819784 \text { to } \\
45.513395,9.051996\end{array}$ \\
\hline $\begin{array}{l}\text { Expo } 2015 \text { (near Milan Fair Rho-Pero) } \\
\text { from } 2012 \text { - in progress }\end{array}$ & & & & & & & & & & & & & & & $45.520796,9.078340$ \\
\hline $\begin{array}{l}\text { Boffalora-Malpensa highway (road } \\
\text { link between S.S n. } 527 \text { and S.S. n. } \\
\text { 11) from September } 2004 \text { to March } \\
2008\end{array}$ & & & & & & & & & & & & & & & $\begin{array}{l}\text { From } 45.467913,8.862821 \text { to } \\
45.588893,8.779394\end{array}$ \\
\hline $\begin{array}{l}\text { FNM (rail link and doubling of the } \\
\text { railway line) from June } 2006 \text { to } \\
\text { January } 2009\end{array}$ & & & & & & & & & & & & & & & $45.577670,8.787510$ \\
\hline $\begin{array}{l}\text { FNM (upgrading of the railway line) } \\
\text { from May } 2011 \text { - in progress }\end{array}$ & & & & & & & & & & & & & & & $\begin{array}{l}\text { From } 45.577670,8.787510 \text { to } \\
45.528013,8.738758\end{array}$ \\
\hline $\begin{array}{l}\text { Adaptation and modernisation of A4 } \\
\text { highway from January } 2012 \text { - in } \\
\text { progress }\end{array}$ & & & & & & & & & & & & & & & $\begin{array}{l}\text { From } 45.473571,8.816284 \text { to } \\
45.490377,8.865858\end{array}$ \\
\hline $\begin{array}{l}\text { Garbagnate General Hospital from } \\
\text { July } 2011 \text { - in progress }\end{array}$ & & & & & & & & & & & & & & & $45.582718,9.097313$ \\
\hline $\begin{array}{l}\text { Legnano General Hospital } \\
\text { from January } 2007 \text { to May } 2010\end{array}$ & & & & & & & & & & & & & & & $45.583940,8.886753$ \\
\hline $\begin{array}{l}\text { D4 (residential building construction } \\
\text { site situated in Assago) from January } \\
2007 \text { - in progress }\end{array}$ & & & & & & & & & & & & & & & $45.406347,9.123984$ \\
\hline Doubling of the railway line Milano- & & & & & & & & & & & & & & & From $45.420613,9.066950$ to \\
\hline
\end{tabular}

Information was accessed via the Local Health Authority Milan 1, UOC SPreSAL, Internal Archive. The "UOC SPreSAL" is the service that controls construction works in the Milan area. Geographical coordinates were found by using Google Maps. Shaded areas show when large construction works were undertaken

development of the terminal flowers (Cockshull and Kofranek 1994). The authors have not been able to identify a causal mechanism that can satisfactorily explain why low relative humidity in June would be beneficial for the production of pollen by Ambrosia plants.

Interestingly, there is evidence to suggest that higher temperatures and humidity can aid the reproduction and survival rates of $O$. communa leaf beetles. It has been shown that increased temperatures shorten the preovipositional period, ovipositional period and longevity of female $O$. communa with the highest amount of oviposition observed at $28{ }^{\circ} \mathrm{C}$. Survival rates of $O$. communa from egg-to-adult stages were also much higher at 25 and $28^{\circ} \mathrm{C}$ (Zhou et al. 2010b). Higher relative humidity also improves survival rates during the egg, larva and entire immature stage of $O$. communa (Zhou et al. 2010a). However, it is suspected that $O$. communa has been present in Europe for less than 5 years (Müller-Schärer et al. 2014), and so it is debatable whether this would be long enough to influence the long-term relationship (2000-2012) between airborne concentrations of Ambrosia pollen and weather conditions in spring and summer.

This study did not simply examine relationships between airborne Ambrosia pollen concentrations and meteorological factors. Regression models were constructed in order to predict the AAP in "below average", "above average" and "low intensity" years. The idea is that failure of the models to satisfactorily predict the AAP in 2013 would corroborate the evidence showing that the observed decrease in airborne concentrations of Ambrosia pollen cannot be explained by meteorology add that the decrease was related to the presence of $O$. communa in the area. The regression models tended to overestimate the amount of Ambrosia pollen recorded in August and September 2013, which indicates that the AAP in this year was much lower than expected. For instance, examination of the relationship between AAP and monthly meteorological data in 2013 (Fig. 3) shows that low minimum temperatures in March, low minimum temperatures and relative humidity in June, and a low number of days with rain in September ought to have resulted in AAP being much higher. This evidence is not conclusive, however, because it should also be remembered that regressions are used to predict the future by examining the past and as such have difficulty modelling extreme values outside the range of data used to construct them.

As seen with airborne Ambrosia pollen, there was a significant decrease in the amount of Urticaceae pollen recorded over the period 2000-2013. In addition, like Ambrosia, the amounts of atmospheric Urticaceae pollen recorded in 2012 and 2013 were lower than in other years in the data set. The lowest amount of 
Cannabaceae pollen was also recorded in 2013. The amount of Cannabaceae and Urticaceae pollen recorded in August and September cannot, therefore, be used to support the hypothesis that meteorology did not play a part in the decrease in airborne concentrations of Ambrosia pollen (i.e. it is possible that inclementwet-weather in August and September 2013 caused Ambrosia, Cannabaceae and Urticaceae pollen concentrations to decrease).

Daily average Ambrosia pollen concentrations in the Milan area were found to be negatively related to daily precipitation, and AAP was negatively correlated with the number of days with precipitation in September (during the main flowering period of Ambrosia). This is related to the release and dispersal of pollen, because precipitation removes bioaerosols from the air (Cox and Wathes 1995). With this in mind, it should be noted that the number of days with precipitation in September 2013 was below average (lower than the 1981-2010 mean) (Table 4). The results of correlation analysis also showed that there are significant positive relationships between daily average concentrations of airborne Ambrosia, Cannabaceae and Urticaceae pollen, which suggests that similar factors, such as meteorology, influence daily variations in the amount of pollen recorded in the air during August and September for all three pollen types. It is interesting to note, therefore, that 2013 was a relatively dry year. August and September 2013 recorded in the third and fifth lowest mean monthly rainfall in the 2000-2013 data set, respectively (data not shown).

It is conceivable that changes in land use could influence airborne concentrations of Ambrosia pollen. Ambrosia has a preference for disturbed sites (Essl et al. 2009), but examination of information from the UOC SPreSAL Internal Archive shows that there is no relationship between construction works and the decrease in atmospheric Ambrosia pollen in the Milan area (Table 6). The implementation of management programmes designed to reduce Ambrosia populations (Ordinanza_Del_Presidente_Della_Regione_Lombardia 1999; Regione_Lombardia 2013) could also be responsible for the reduction in atmospheric concentrations Ambrosia pollen, as well as airborne pollen from other plants growing on similar habitats. It is therefore important to note that the regional instructions for Ambrosia containment specify that the plant should be controlled in both ruderal and agricultural habitats, and so management could partly explain the decreases seen in Ambrosia, Cannabaceae and Urticaceae pollen concentrations.

\section{Conclusions}

The results of this study do not reject the hypothesis that the observed decrease in airborne Ambrosia pollen was mainly due to the presence of large numbers of $O$. communa in the Milan area. There is some evidence to suggest that, based on weather conditions in 2013, airborne Ambrosia pollen concentrations should have been higher than recorded and that the drastic decrease in AAP in 2013 cannot be explained by meteorology alone. It is necessary to determine to what degree the presence of $O$. communa will benefit the allergic population, and so studies are presently underway that will further assess the effects of the ragweed leaf beetle infestations on local pollen production and local and regional concentrations of airborne Ambrosia pollen.

Acknowledgments We acknowledge support from EU COST Action FA1203 "Sustainable management of Ambrosia artemisiifolia in Europe (SMARTER)" (http://ragweed.eu). This work was partly financed by the Ministry of Science, Republic of Serbia (project numbers OI173002 and III43002) and the COST-STSM-FA1203-16674 to BS. The authors are grateful to Dott. Marina della Foglia, responsible of the UOC SPreSAL of the Local Health Authority Milan 1 and to Mrs. Marilena Pisoni for providing information about construction sites in the study area.

\section{References}

Baskin, J. M., \& Baskin, C. C. (1977). Dormancy and germination in seeds of common ragweed with reference to Beals buried seed experiment. American Journal of Botany, 64, 1174-1176.

Baskin, J. M., \& Baskin, C. C. (1980). ecophysiology of secondary dormancy in seeds of Ambrosia artemisiifolia. Ecology, 3, 475-480.

Bickel, R. (2012). Multilevel analysis for applied research: It's just regression! (Methodology in the social sciences). New York: Guilford Press.

Bosio, G., Massobrio, V., Chersi, C., Scavarda, G., \& Clark, S. (2014). Spread of the ragweed leaf beetle, Ophraella communa LeSage, 1986 (Coleoptera Chrysomelidae), in Piedmont Region (Northwestern Italy). Bollettino della Società Entomologica Italiana, 146(1), 17-30.

Cockshull, K. E., \& Kofranek, A. M. (1994). High night temperatures delay flowering, produce abnormal flowers and 
retard stem growth of cut-flower chrysanthemums. Scientia Horticulturae, 56, 217-234.

Comtois, P. (1998). Statistical analysis of aerobiological data. In Mandrioli, P., Comtois P. and V. Levizzani (eds.) Methods in aerobiology. Italy: Pitagora EditriceBologna.

Cox, C. S. \& Wathes, C. M. (1995). Bioaerosols handbook. USA: Lewis Publishers.

Dahl, Å., Galán, C., Hajkova, L., Pauling, A., Sikoparija, B. Smith, M., et al. (2013). The onset, course and intensity of the pollen season. In M. Sofiev \& K.-C. Bergmann (Eds.), Allergenic Pollen (pp. 29-70). Netherlands: Springer.

Dahl, A., Strandhede, S.-O., \& Wihl, J.-A. (1999). RagweedAn allergy risk in Sweden? Aerobiologia, 15(4), 293-297.

Essl, F., Dullinger, S., \& Kleinbauer, I. (2009). Changes in the spatio-temporal patterns and habitat preferences of Ambrosia artemisiifolia during its invasion of Austria. Preslia, 81(2), 119-133.

Fumanal, B., Chauvel, B., \& Bretagnolle, F. (2007). Estimation of pollen and seed production of common ragweed in France. Annals of Agricultural and Environmental Medicine, 14, 233-236.

Futuyma, D. J., Keese, M. C., \& Scheffer, S. J. (1993). Genetic constraints and the phylogeny of insect-plant associations: responses of Ophraella communa (Coleoptera: Chrysomelidae) to host plants of its congeners. Evolution, 47(3), 888-905.

Futuyma, D. J., \& MCCafferty, S. S. (1990). Phylogeny and the evolution of host plant associations in the leaf beetle genus Ophraella (Coleoptera, Chrysomelidae). Evolution, 44, 1885-1913.

Gerber, E., Schaffner, U., Gassmann, A., Hinz, H. L., Seier, M., \& Müller-Schärer, H. (2011). Prospects for biological control of Ambrosia artemisiifolia in Europe: Learning from the past. Weed Research, 51(6), 559-573.

Guo, J.-Y., Zhou, Z.-S., Zheng, X.-W., Chen, H.-S., Wan, F.-H., \& Luo, Y.-H. (2011). Control efficiency of leaf beetle, Ophraella communa, on the invasive common ragweed, Ambrosia artemisiifolia, at different growing stages. Biocontrol Science and Technology, 21(9), 1049-1063.

Hirst, J. M. (1952). An automatic volumetric spore trap. The Annals of Applied Biology, 39(2), 257-265.

Meng, L., \& Li, B. (2005). Advances on biology and host specificity of the newly introduced beetle, Ophraella communa Lesage (Coleoptera: Chrysomelidae), attacking Ambrosia artemisiifolia (Compositae) in continent of China. Chinese Journal of Biological Control, 21(2), 65-69.

Müller-Schärer, H., Lommen, S. T. E., Rossinelli, M., Bonini, M., Boriani, M., Bosio, G., et al. (2014). Ophraella communa, the ragweed leaf beetle, has successfully landed in Europe: Fortunate coincidence or threat? Weed Research, 54(2), 109-119.

Ordinanza_Del_Presidente_Della_Regione_Lombardia (1999). O.P.G.R. 29 marzo 1999-n. 25522. Ordinanza contingibile e urgente ai sensi dell' art. 32 della legge 23 dicembre 1978, n.833. Disposizioni contro la diffusione della pianta Ambrosia nella Regione Lombardia al fine di prevenire la patologia allergica ad essa correlata: Bolletino Ufficiale della Regione Lombardia. Serie Ordinaria N.15, 12 aprile 1999.

Pallant, J. (2001). SPSS survival manual. Maidenhead: Open University Press.
Palmer, W. A., \& Goeden, R. D. (1991). The host range of Ophraella communa Lesage (Coleoptera: Chrysomelidae). Coleopterists Bulletin, 45, 115-120.

Pickett, S. T., \& Baskin, J. M. (1973). The role of temperature and light in the germination behaviour of Ambrosia artemisiifolia. Torrey Botanical Society, 100, 165-170.

Prentović, M., Radišić, P., Smith, M., \& Šikoparija, B. (2014). Predicting walnut (Juglans spp.) crop yield using meteorological and airborne pollen data. Annals of Applied Biology In press.

Regione_Lombardia (2013). Prevenzione delle allergopatie da ambrosia in Lombardia

Rogers, C., Wayne, P. M., Macklin, E. A., Muilenberg, M. L., Wagner, C. J., Epstein, P. R., et al. (2006). Interaction of the onset of spring and elevated atmospheric $\mathrm{CO}_{2}$ on ragweed (Ambrosia artemisiifolia L.) pollen production. Environmental Health Perspectives, 114(6), 865-869.

Skjøth, C. A., Smith, M., Sikoparija, B., Stach, A., Myszkowska, D., Kasprzyk, I., et al. (2010). A method for producing airborne pollen source inventories: An example of Ambrosia (ragweed) on the Pannonian Plain. Agricultural and Forest Meteorology, 150, 1203-1210.

Smith, M., Cecchi, L., Skjoth, C. A., Karrer, G., \& Sikoparija, B. (2013). Common ragweed: A threat to environmental health in Europe. Environment International, 61, 115126.

Stach, A., Smith, M., Prieto Baena, J. C., \& Emberlin, J. (2008). Long-term and short-term forecast models for Poaceae (grass) pollen in Poznań, Poland, constructed using regression analysis. Environmental and Experimental Botany, 62, 323-332.

Sterling, M., Rogers, C., \& Levetin, E. (1999). An evaluation of two methods for microscopic analysis of airborne fungal spore concentrations from the Burkard spore trap. Aerobiologia, 15, 9-18.

Takizawa, H. A., Saito, A., Sato, K., Hirano, Y., \& Ohno, M. (1999). Invading insect, Ophraella communa LeSage, 1986. Range expansion and life history in Kanto District, Japan. Gekkanlushi, 338, 26-31.

Tanaka, K., \& Yamanaka, T. (2009). Factors affecting flight activity of Ophraella communa (Coleoptera: Chrysomelidae), an exotic insect in Japan. Environmental Entomology, 38(1), 235-241.

Teshler, M. P., Ditommaso, A., Gagnon, J. A., \& Watson, A. K. (2002). Ambrosia artemisiifolia L., common ragweed (Asteraceae). In J. T. Huber (Ed.) Biological control programmes in Canada New York (pp. 290-294), USA CABI Publishing.

Wan, F.-H., Guo, J.-Y. \& Zhang, F. (2009). Research on biological invasions in China. Beijing: Science press.

Willemsen, R. W. (1975). Effect of stratification temperature and germination temperature on germination and induction of secondary dormancy in common ragweed seeds. American Journal of Botany, 62, 1-5.

Yamamura, K., Moriya, S., Tanaka, K., \& Shimizu, T. (2007). Estimation of the potential speed of range expansion of an introduced species: characteristics and applicability of the gamma model. Population Ecology, 49(1), 51-62.

Zhou, Z.-S., Chen, H.-S., Zheng, X.-W., Guo, J.-Y., Guo, W., Li, M., et al. (2014). Control of the invasive weed Ambrosia artemisiifolia with Ophraella communa and Epiblema 
strenuana. Biocontrol Science and Technology, 24(8), 950-964.

Zhou, Z.-S., Guo, J.-Y., Chen, H.-S., \& Wan, F.-H. (2010a). Effect of humidity on the development and fecundity of Ophraella communa (Coleoptera: Chrysomelidae). BioControl, 55(2), 313-319.

Zhou, Z.-S., Guo, J.-Y., Chen, H.-S., \& Wan, F.-H. (2010b). Effects of temperature on survival, development, longevity, and fecundity of Ophraella communa (Coleoptera: Chrysomelidae), a potential biological control agent against Ambrosia artemisiifolia (Asterales: Asteraceae). Environmental Entomology, 39(3), 1021-1027.
Zhou, Z.-S., Guo, J.-Y., Zheng, X.-W., Luo, M., Chen, H.-S., \& Wan, F.-H. (2011). Reevaluation of biosecurity of Ophraella communa against sunflower (Helianthus annuus). Biocontrol Science and Technology, 21(10), 1147-1160.

Zhu, D. H., Zhu, J., Peng, Z. P., \& Wan, F. H. (2012). Effects of photoperiod and temperature on reproductive diapause in Ophraella communa (Coleoptera: Chrysomelidae), a potential biocontrol agent against Ambrosia artemisiifolia. Insect Science, 19(3), 286-294. 